\title{
A BÜKKALJA VÖLGYHÁLÓZATÁNAK RENDÜSÉG SZERINTI IRÁNYSTATISZTIKAI VIZSGÁLATA
}

\author{
Pecsmány Péter \\ PhD hallgató, Miskolci Egyetem, Természetföldrajz-Környezettan Intézeti Tanszék \\ 3515 Miskolc, Miskolc-Egyetemváros, e-mail: ecopeter@uni-miskolc.hu
}

\begin{abstract}
Absztrakt
A vizfolyások rendüségének kvantitativv vizsgálata nem új keletü dolog a vízgyüjtők, vízrendszerek vizsgálatában. A módszer lényege, hogy elsörendünek tekintjük a forráságakat, majd két elsörendü völgy találkozásából egy másodrendü völgy születik (igy tovább...). Az azonos rendü völgyek eggyel emelik a rendüséget, míg két eltérö rendü völgy találkozása nem jár rendüség emelkedéssel. A vizsgálat segitségével következtetéseket tudunk levonni az adott völgyszakasz nagyságára, vízrendszerben betöltött szerepére, valamint akár korára. Munkámban a Bükkalján futó völgyek rendüségét és azok irányát vizsgáltam meg és vetettem össze a szakirodalomban eddig közölt eredményekkel.
\end{abstract}

Kulcsszavak: völgyhálózat, rendüség, Bükkalja, iránystatisztika

\begin{abstract}
Quantitative analysis of stream-order is not a new thing in the study of drainage basins and river systems. The essence of the method is to consider the source branches as first-order, and then from the meeting of two first-order valleys a second-order valley is born (so on...). Valleys of the same order increase order by one, while the encounter of two valleys of different order does not increase order. Analysing the stream-order, we can draw conclusions about the size of the given valley section, its role in the river system, and even its age. In my work I examined the order of the valleys running in Bükkalja and their direction and I compared my findings with the results published in the literature so far.
\end{abstract}

Keywords: drainage network, stream-order, Bükkalja, orientation

\section{Bevezetés}

A vízfolyások kvantitatív alapú vizsgálatával elsőnek Horton, R.E. [1] foglalkozott, aki bevezette a rendűség fogalmát. Elsőrendűnek tekintette a forráságakat, vagyis az első összefolyásig terjedő völgyszakaszokat. Két elsőrendủ vízfolyás/völgy találkozása egy másodrendủ völgyet eredményez (így tovább...). Az azonos rendủ völgy találkozása emeli a rendszámot, azonban különböző rendủ völgyszakaszok találkozása esetében nincs rendszám növekedés. Strahler, A.N. [2] később annyiban módosította Horton, R.E. [1] metódusát, hogy a torkolatnál kapott végleges rendszámot nem vetítette vissza a teljes vízgyüjtőre. Bár az eljárást Horton, R.E. [1] fejlesztette ki, mégis a Strahler, A.N. [2] módszereként terjedt el. A rendűség vizsgálatát már évtizedek óta alkalmazzák a víz- és völgyhálózat kvantitatív alapú elemzésére, hiszen következtethetünk belőle a méretükre, vízgyüjtöben/vízrendszerben elfoglalt helyükre, valamint akár korukra is $[1,2]$. 
Munkámban arra keresek választ, hogy a Bükkalján futó völgyek irányítottsága és rendűsége között kimutatható-e kapcsolat, és ha igen, akkor azok milyen, a terület szakirodalomból ismert jellemzőivel állhatnak kapcsolatban.

\section{Anyag és módszer}

Mivel a Bükkalja területén az állandó vízfolyással rendelkező völgyek száma csekély, így az iránystatisztikai vizsgálatokhoz nem a vízfolyás-, hanem a sürübb völgyhálózatot használtam fel, ezt más terület szerkezetmorfológiai vizsgálatánál is sikeresen alkalmazták [3,4].

A völgyhálózat elkészítésének egyik - a hagyományos digitalizálással történő módszerrel szemben kevésbé szubjektív - módja a digitális domborzat- vagy terepmodellből való származtatás. Az elméleti völgyhálózat elkészítéséhez a 25 m-es térbeli felbontású HydroDEM-et használtam fel. Először a terepmodellben található lefolyástalan területeket az ArcGIS térinformatikai szoftverben beépített Fill parancs segítségével töltöttem fel, erre azért volt szükség, hogy összefüggő vízhálózatot lehessen származtatni. Ezt követően a Flow Direction parancs segítségével meghatároztam a lefolyási viszonyokat, majd a Flow Accumlation parancs felhasználásával meghatároztam, hogy az egyes képpontokba (cellákba) mekkora területről érkezhet víz. Az utolsó lépésben a kritikus forrásterületet kellett megállapítani $[4,5]$, amely meghatározza azt, hogy legalább mekkora vízgyüjtő területtel kell rendelkeznie a cellának rendelkezni ahhoz, hogy vízfolyás részének tekinthessük $[4,6]$.

A terepi megfigyeléseimet is szem elött tartva $0,2 \mathrm{~km}^{2}$ és $1 \mathrm{~km}^{2}$-es kritikus forrásterületet választottam. A $0,2 \mathrm{~km}^{2}$-es területegység esetében jól térképezhetők a mellékvölgyek, az $1 \mathrm{~km}^{2}$-es forrásterület alkalmazása pedig - mint már azt Hegedűs A. [6] is megállapította - jól egyezik a „kékvonal” módszerrel. A $0,2 \mathrm{~km}^{2}$-es területegység esetében a domborzatmodell „elégtelen” felbontása miatt, a széles völgytalpakon lejtésiránnyal párhuzamosan „fenyőfa” alakrajzú „hamis völgyek” is megjelentek, az ilyen kis küszöbérték esetében ez nem szokatlan [4, 7]. Ezek a széles völgytalpakon (Eger-, Hór-patak) lehetnek hajdani medermaradványok is, de mivel egy völgyröl beszélünk, ezért a MrVBF-et (Multiresolution Index of Valley Bottom Flatness) [8] és TPI-t (Topographic Position Index) [9, 10] felhasználva ezeket a hibákat vizuális kiértékelés alapján eltávolítottam az állományból.

Az elméleti völgyhálózat elkészítése után az ArcGIS Generalize parancsa segítségével elsimítottam a kisebb, lokális léptékű (100 m) változásokat (szakaszokat). Erre azért volt szükség, hogy a völgyirányokban jelentkező 5-10 fokos kilengéseket kiegyenlítsem, hiszen ezek pusztán a mederváltozás útján is kialakulhattak [11] (1. ábra, 2. ábra).

A származtatott völgyhálózat felhasználásával az ArcGIS-ben beépített Stream order modul segítségével elkészítettem el a Strahler-féle rendűség térképet. A Bükkalján a vízfolyások rendüségével Vágó J. [12] már foglalkozott. Ö a rendüséget a Bükkalja területétől számította és csak a „kékvonal” módszerrel meghatározott vízfolyásokat vizsgálta meg. Mivel a Bükkalja vízfolyásainak (fövölgyeinek) vízgyüjtő területe sok esetben jóval túlnyúlik a vizsgált területen (pl.: Laskó-, Eger-, Hór-patak), ezért a rendűség megállapítása során a teljes vízgyüjtő területet vettem figyelembe.

A vonalas elemek (vízhálózat) töréspontjai segítségével szakaszoltam a vízfolyásokat, majd kiszámoltam az egyes szakaszok azimutális irányát, majd RockWorks 16 szoftver segítségével 10 fokos beosztásközzel gyakorisági és hossziránygyakorisági rózsadiagramokat készítettem azokból. 


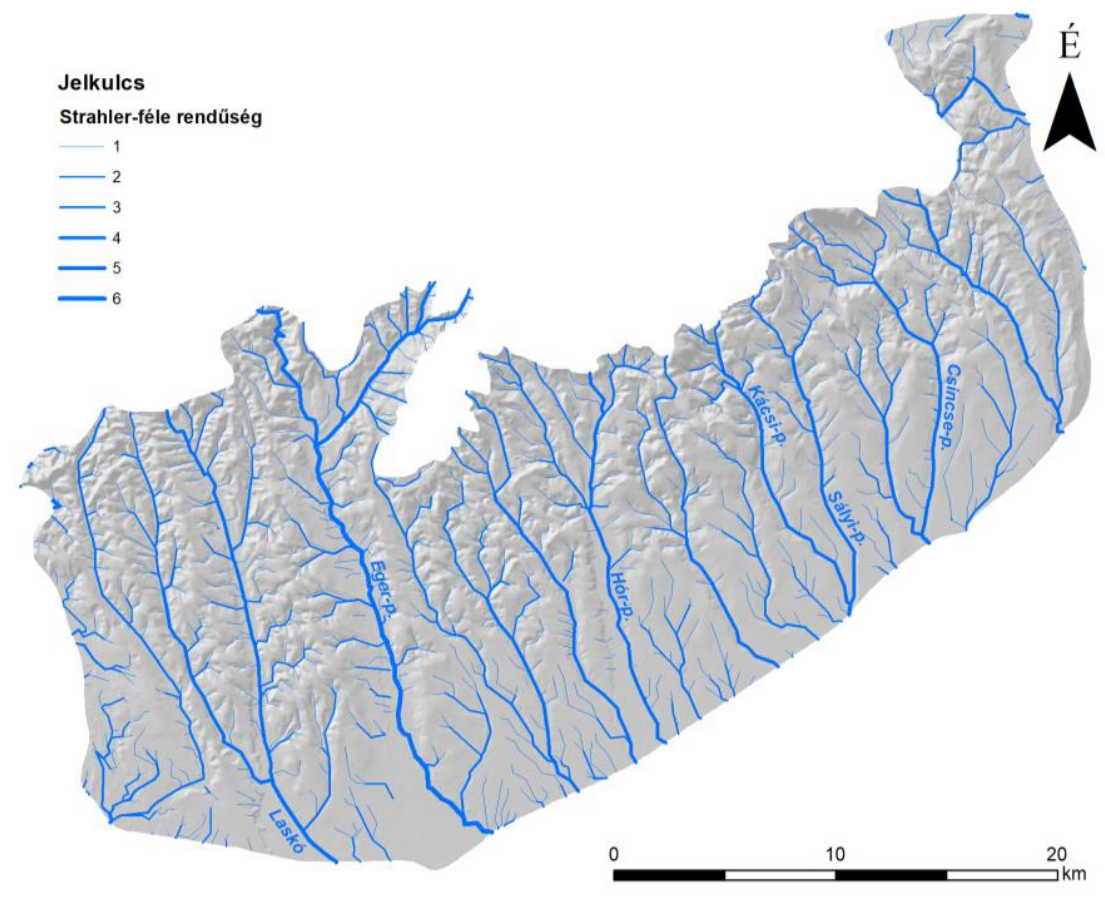

1. ábra. A Bükkalja 0,2 $\mathrm{km}^{2}$-es kritikus forrásterülettel számolt ,javitott” völgyhálózata és annak rendüsége

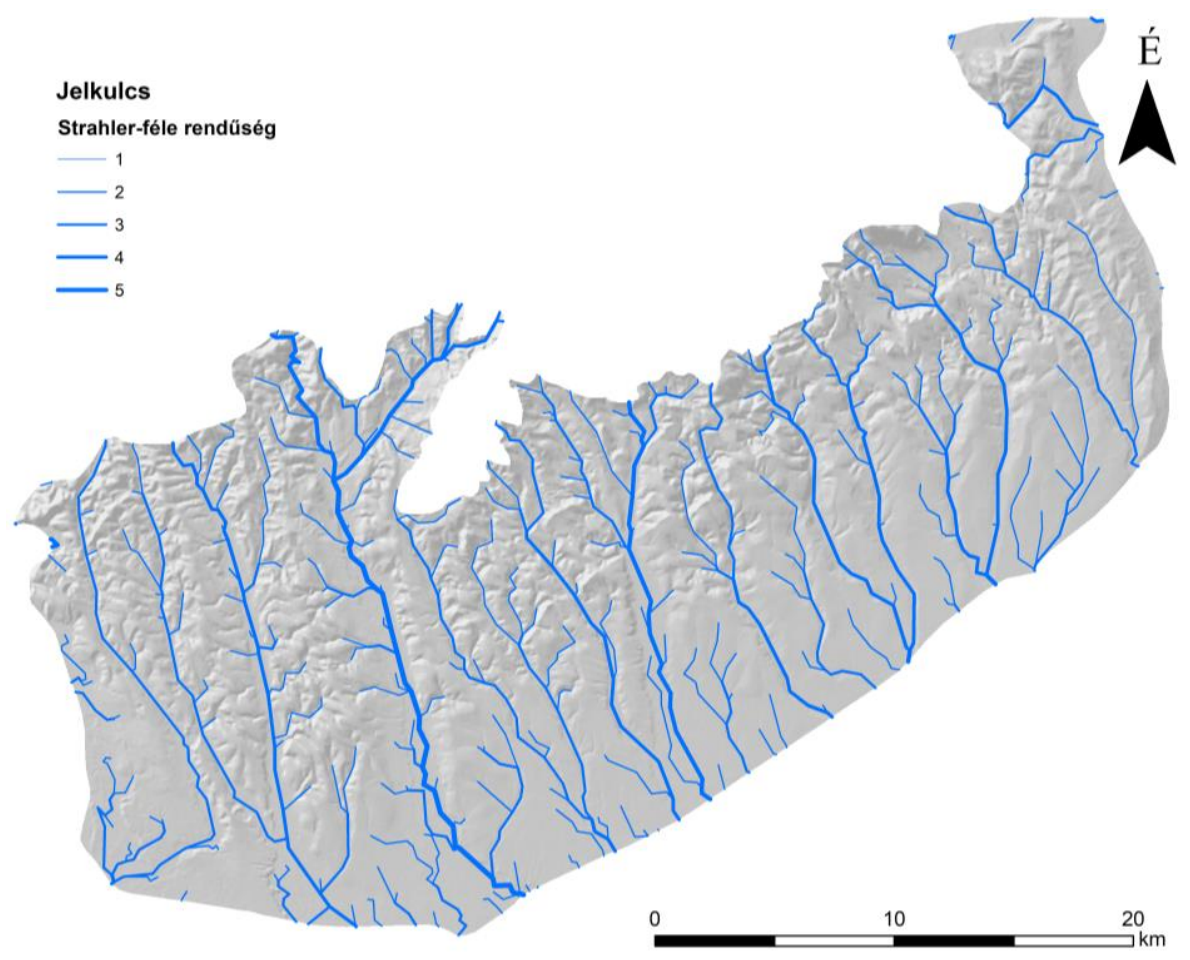

2. ábra. A Bükkalja $1 \mathrm{~km}^{2}$-es kritikus forrásterülettel számolt völgyhálózata és annak rendüsége 


\section{Eredmények}

\subsection{Teljes völgyhálózat iránystatisztikai vizsgálata}

A $0,2 \mathrm{~km}^{2}$ kritikus forrásterülettel számolt elméleti vízhálózatnál az eredeti és a javított („hamis völgyek" nélküli) állomány között sem irány-, sem hosszirány gyakoriságban jelentős eltérés nincs. Gyakoriság alapján a völgyek nagyrészt É-D-i irányúak, azonban az ÉNy-DK-i irány is megjelenik. Hosszirány gyakoriság alapján az ÉÉNy-DDK-i irányú völgyek vannak többségben. Az $1 \mathrm{~km}^{2}$-es kritikus forrásterülettel számolt völgyhálózat is ÉÉNy-DDK-i irányítottságot mutat, mind irány-, mind pedig hosszirány gyakoriság alapján (3. ábra).

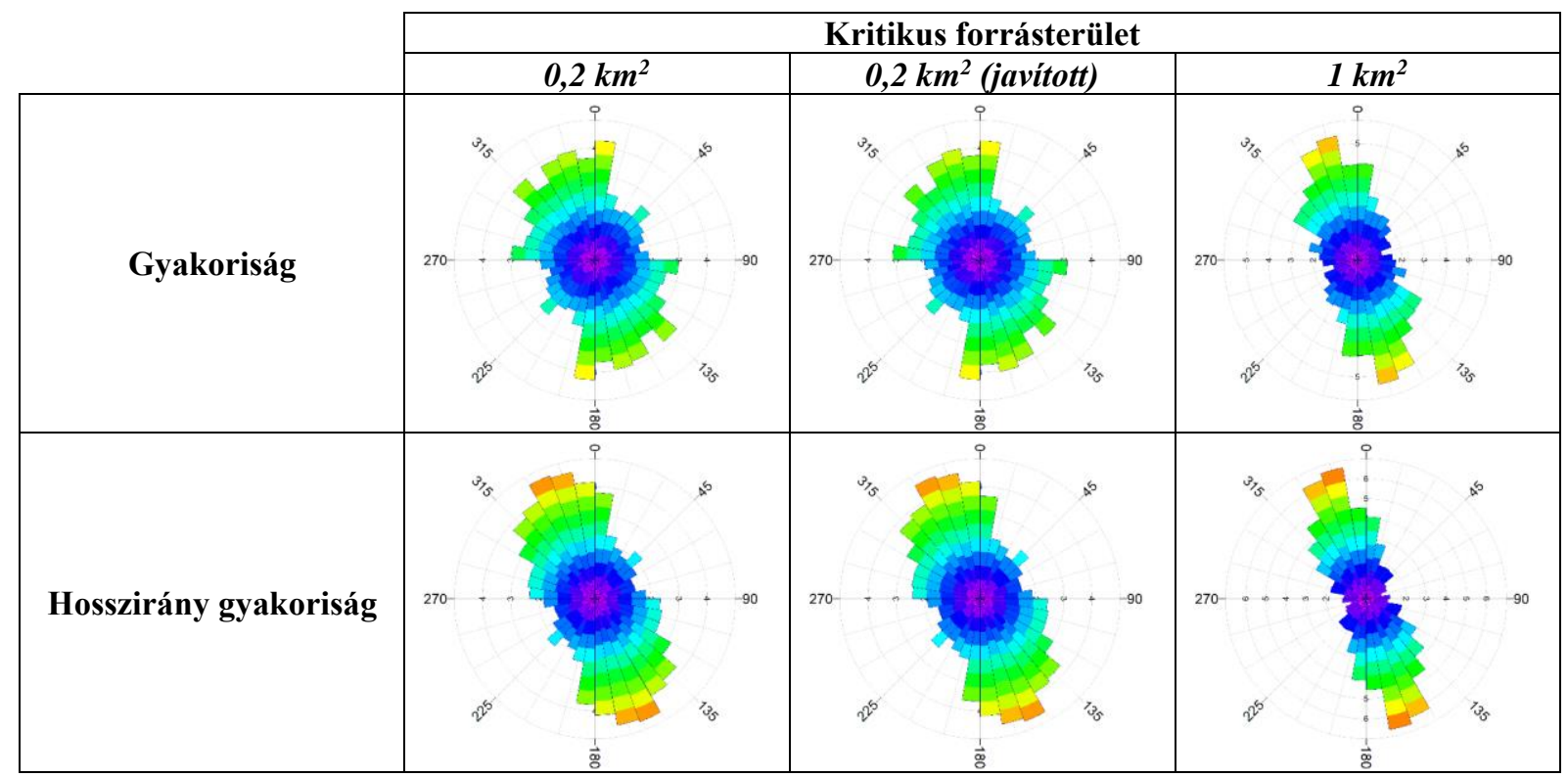

3. ábra. A Bükkalja különbözö kritikus forrásterülettel származtatott völgyhálózatának irány- és hosszirány gyakorisága

\subsection{Rendúség szerinti statisztikai vizsgálat}

Az iránystatisztikai vizsgálatnál mind a két forrásterület méret esetében az utolsó két osztályba (rendüségbe) tartozó szakaszokat együtt kezeltem. Ennek két oka volt: egyrészt az, hogy ezekbe a többi rendüségi osztályhoz képest sokkal kevesebb elem (szakasz) került (1. táblázat), másrészt pedig a legnagyobb rendüségi $\left(0,2 \mathrm{~km}^{2}\right.$-nél hatodrendü, $1 \mathrm{~km}^{2}$-nél ötödrendü) csoportba csak egy völgy tartozott bele, az Eger-patak völgye (ennek oka az, hogy a vízgyüjtő területe jóval túlterjed a Bükkalján és több jelentősebb völgy [pl.: Tárkányi-patak völgye] torkollik bele, amely emeli a rendszámot). Az említett tényezők nagyon elnyomták volna a statisztikai elemzés eredményét, ezért döntöttem az összevonás mellett.

A $0,2 \mathrm{~km}^{2}$-es kritikus forrásterülettel számolt elméleti völgyhálózat, és annak javított változata között az iránystatisztikai vizsgálatoknál jelentős különbséget nem tapasztaltam. 
1. táblázat. Kritikus forrásterületenként számolt rendüségek eloszlása

\begin{tabular}{|r|c|c|c|c|c|c|}
\cline { 2 - 7 } \multicolumn{1}{c|}{} & \multicolumn{3}{c|}{ Kritikus forrásterület } \\
\cline { 2 - 7 } & \multicolumn{2}{c|}{$\mathbf{0 , 2} \mathbf{k m}^{\mathbf{2}}$} & \multicolumn{2}{c|}{$\mathbf{0 , 2} \mathbf{k m}^{\mathbf{2}}$ (javított) } & \multicolumn{2}{c|}{$\mathbf{~ k m}^{\mathbf{2}}$} \\
\cline { 2 - 7 } & szakasz $(\mathrm{db})$ & hossz $(\mathrm{km})$ & szakasz $(\mathrm{db})$ & hossz $(\mathrm{km})$ & szakasz $(\mathrm{db})$ & $\mathrm{hossz}(\mathrm{km})$ \\
\hline elsőrendü & 1086 & 622,5233 & 913 & 546,21 & 224 & 316,80 \\
\hline másodrendü & 444 & 287,14 & 386 & 255,97 & 110 & 196,31 \\
\hline harmadrendü & 263 & 180,05 & 243 & 63,80 & 58 & 102,34 \\
\hline negyedrendü & 267 & 147,09 & 267 & 147,09 & 29 & 35,04 \\
\hline ötödrendü & 49 & 22,31 & 49 & 22,31 & 17 & 20,83 \\
\hline hatodrendü & 49 & 20,97 & 49 & 20,97 & - & - \\
\hline
\end{tabular}

Az elsőrendủ völgyek nem mutatnak irányítottságot iránygyakoriság alapján. A fö és mellékégtájak közel azonos arányban vannak jelen. A javított állomány esetében a $\mathrm{K}-\mathrm{Ny}-\mathrm{i}$ irány enyhén dominánsan jelenik meg az iránygyakorisági rózsadiagramon. Hosszirány gyakoriság alapján az ÉNy-DK-i irány dominál, azonban az É-D-i irány is hangsúlyosan jelenik meg. A másodrendủ völgyek esetében az ÉNy-DK-i irány a leggyakoribb és itt is megjelenik az É-D-i irány. Hosszirányt tekintve ugyanezek az irányok dominálnak, annyi eltéréssel, hogy a javított állomány esetében az É-D-i irány kevésbé hangsúlyos. Ennek oka az, hogy a széles völgytalpakon futó, eltávolított „hamis” völgyek nagyobbrészt É-D-i irányítottságúak voltak. A harmadrendü völgyeknél mindkét esetben a leggyakoribb irány az ÉÉNy-DDK-i. Az adatok nagyobb része mind a két esetben ÉNy-DK és É-D-i irány közé csoportosult. A negyedrendü völgyek esetében is ugyanaz figyelhető meg, mint a harmadrendűeknél, azonban az adatok itt már kevésbé szórnak. Az összevont ötöd- és hatodrendü völgyek iránya ismét jobban szór. Irány- és hosszirány gyakoriság alapján az ÉNy-DK és az ÉÉNy-DDK-i irányú völgyek vannak túlsúlyban, azonban főleg a hosszirány gyakoriság alapján megjelenik még egy erre merőleges ÉKDNy-i irány.

Az $1 \mathrm{~km}^{2}$-es kritikus forrásterülettel számolt elméleti völgyhálózat elsőrendű völgyei ÉÉNy-DDKi irány körül összpontosulnak irány- és hosszirány gyakoriság szerint is. A másodrendü völgyeknél mind irány-, mind hosszirány gyakoriság alapján szintén az előbb már említett ÉÉNy-DDK-i irány dominál. A harmadrendü völgyek iránya már kevésbé szórt. Két markánsan megjelenő irány figyelhető meg (ÉÉNy-DDK, É-D), de a domináns irány itt is ÉÉNy-DDK. Az összevont negyed- és ötödrendủ völgyek irányai már ismételten jobban szórnak. Az adatok szintén ÉÉNy-DDK-i irány körül csoportosulnak. Itt is megjelenik, hasonlóan, mint a $0,2 \mathrm{~km}^{2}$-es területegységgel számolt ötöd- és hatodrendủ völgyek esetében, egy erre közel merőleges ÉK-DNy-i irány (4. ábra).

$\mathrm{Az} 1 \mathrm{~km}^{2}$-es rózsadiagramokon láthatjuk, hogy minden rendüség esetében ugyanaz az ÉÉNyDDK-i irány a meghatározó. Ez alapján arra következtetek, hogy az ilyen méretü, már az esetek nagy részében vízfolyással rendelkező szakaszok, tehát a vízhálózat rajzolattípusa párhuzamos. A $0,2 \mathrm{~km}^{2}-$ es, kis forrásterületü szakaszok - azaz a völgyhálózat - iránystatisztikája alapján a Bükkalja teljes völgyhálózata ágas rajzolatú.

\subsection{A völgyiránystatisztikai eredmények és a szakirodalmi adatok összehasonlítása}

A szakirodalomban a terület általános lejtésiránya, valamint a szerkezeti elemek sajátosságai már ismertek. A Bükkalja területén az általános lejtésirány DDK-i [12], a fötörések iránya ÉK-DNy-i, de ezekre kialakultak haránt- és diagonális törések is $[13,14,15,16]$. 


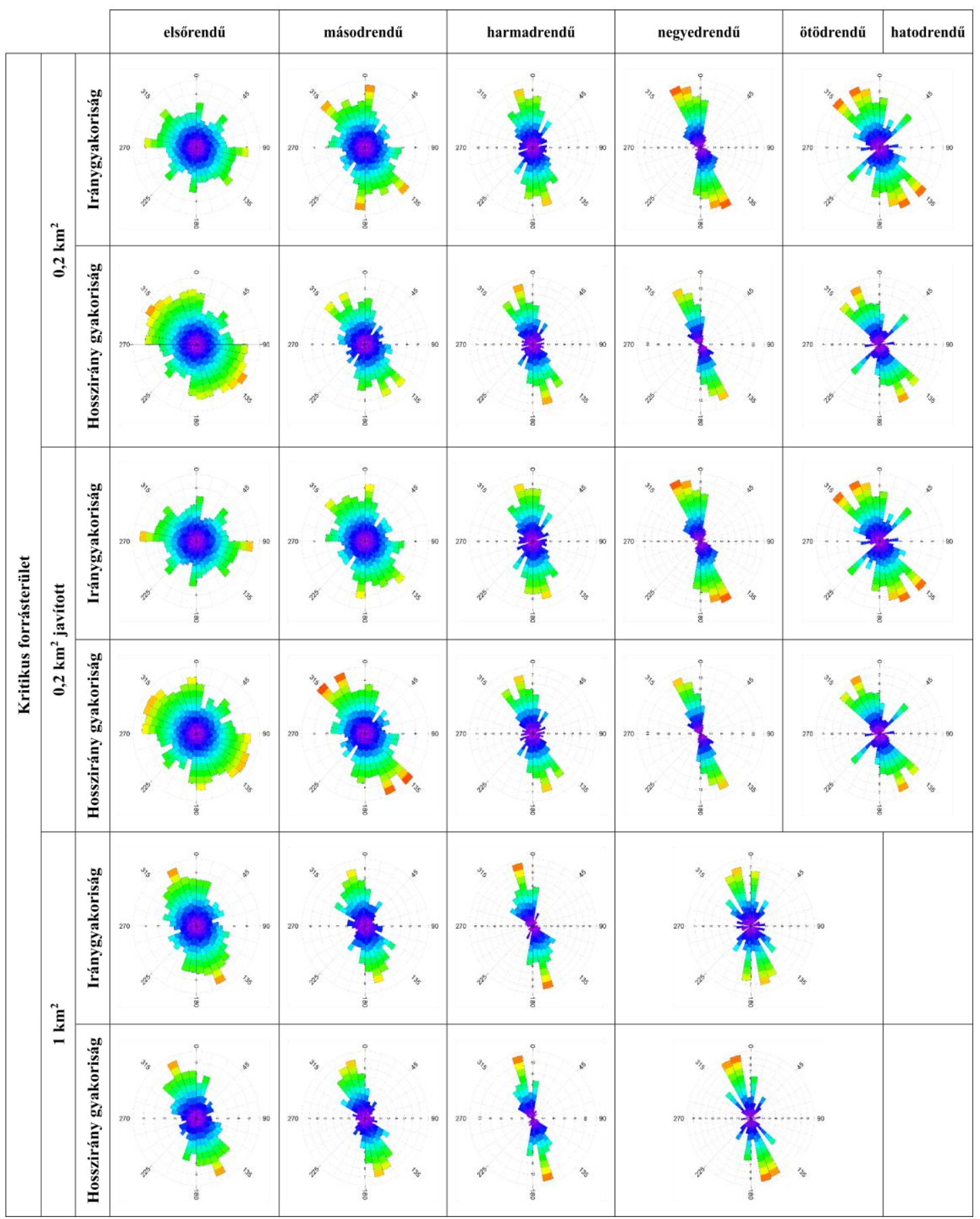

4. ábra. A Bükkalja különbözö kritikus forrásterülettel származtatott völgyhálózatának rendüség szerinti irány- és hosszirány gyakorisága 
A teljes völgyhálózatot vizsgálva az ÉÉNy-DDK-i völgyirány a leggyakoribb, ami a Bükkalja ÉNy-DK-i irányú haránttörésével és az általános lejtésiránnyal hozható kapcsolatba. A néhány fokos eltérést az általános lejtés, a haránttörések és a völgyhálózat iránya között a kőzetminőségbeli különbségekre lehet visszavezetni, amivel alapvetően számolnunk kell a Bükkalja területén [12]. A főtörések irányát (ÉK-DNy) csak néhány völgy követi, de ez az irány is megjelenik a rózsadiagramokon, bár kevésbé hangsúlyosan.

A $0,2 \mathrm{~km}^{2}$-es kritikus forrásterülettel számolt elméleti völgyhálózat elsőrendü völgyeinél csak a hosszirány gyakoriság esetében figyelhető meg irányítottság, mely szerint föként a haránttörésekre és a diagonális törésekre jellemző ÉK-DNy-i és É-D-i irányt követik. A fötörésekre jellemző ÉK-DNy-i irány is megjelenik, azonban kevésbé számottevően. A másodrendű völgyek nagyrészt a haránt és diagonális törésirányokat követik, a fötörések iránya itt sem jelentős. A harmadrendü völgyek iránygyakoriság alapján ÉÉNy-DDK-i irány felé tolódtak el, de közel állnak a haránt- és diagonális törések irányához.

Hosszirány gyakoriság alapján azonban már csak a haránttöréshez közel álló irány a meghatározó. A negyedrendủ völgyek esetében ugyanez a helyzet áll fenn. Az iránystatisztikában összevont ötöd- és hatodrendű völgyek esetében a haránttörésre jellemző ÉNy-DK-i és ahhoz közelálló ÉÉNy-DDK-i irány dominál, mind irány-, mind hosszirány gyakoriság alapján. A második meghatározó irány, iránygyakoriság alapján a diagonális törések irányával egyezik meg, míg hosszirány gyakoriság esetében a fötörésekre jellemző ÉK-DNy-i irány a jelentős.

Az $1 \mathrm{~km}^{2}$-es kritikus forrásterülettel számolt elméleti völgyhálózat esetében az elsőrendü völgyeknél a haránttörések irányához közeli ÉÉNy-DDK-i irány dominál, jelentős még a diagonális törésekre jellemző irány, a fötörések iránya azonban nem számottevő. A másodrendű völgyek esetében a haránttörések irányához szintén közeli ÉÉNy-DDK-i irány jelenik meg markánsan. A diagonális és haránttörések irányai közel azonos hangsúlyúak, de kevésbé jelentősek. A harmadrendü völgyek esetében gyakoriság alapján a haránttörések ÉNy-DK-i (ÉÉNy-DDK) iránya jelentős, de megjelenik a diagonális törésekre jellemző É-D-i irány is. Az összevont negyed- és ötödrendü völgyek esetében gyakoriság alapján a haránttörésekre jellemző irány dominál, közel azonos hangsúllyal, de jelentősen megjelennek a diagonális és fötörésirányok is.

\section{4. Összefoglalás}

Munkámban a Bükkalja völgyhálózatának iránystatisztikai vizsgálatát végeztem el. A $0,2 \mathrm{~km}^{2}$-es kritikus forrásterülettel számolt völgyhálózat iránygyakoriság alapján É-D-i irányt mutat, míg a $1 \mathrm{~km}^{2}$-es területtel számolt völgyhálózat zömében ÉÉNy-DDK-i futású. Hosszirány gyakoriság esetében mind a két forrásterület esetében az ÉÉNy-DDK-i irányú völgyek vannak többségben. Ez az irány közel megegyezik a Bükkalja általános lejtésirányával és a területen futó földtani szerkezeti elemek haránttöréseinek irányával, a néhány fokos estérést a kőzetminőségbeli változásokra, valamint a pusztán regressziós völgyfejlődésre lehet visszavezetni.

Rendűség alapján a Bükkalja völgyhálózata párhuzamosnak tünik, ami nem jellemző a teljes Bükkaljára [12]. Párhuzamos rajzolat - az eddigi kutatások alapján - csak a riolittufa sávtól délre fekvő területnek jellemvonása, a tufasávban jellemzően lugasos/ágas rajzolatú völgyhálózat alakult ki [12]. Fontos azonban megjegyezni, hogy a vizsgálat eredménye nagyban függ a kiválasztott kritikus forrásterület nagyságától. 


\section{Köszönetnyilvánítás}

A cikkben ismertetett kutató munka az EFOP-3.6.1-16-2016-00011 jelü „Fiatalodó és Megújuló Egyetem - Innovatív Tudásváros - a Miskolci Egyetem intelligens szakosodást szolgáló intézményi fejlesztése" projekt részeként - a Széchenyi 2020 keretében - az Európai Unió támogatásával, az Európai Szociális Alap társfinanszírozásával valósul meg.

\section{Irodalom}

[1] Horton, R. E.: Erosional development of streams and their drainage basins; hydrophysical approach to quantitative morphology, GSA Bulletin 56 (3), (1945) pp. 275-370. https://doi.org/10.1130/0016-7606(1945)56[275:EDOSAT]2.0.CO;2

[2] Strahler, A. N.: Quantitative analysis of watershed geomorphology, Transaction of the American Geophysical Union 38, (1957) pp. 913-920. https://doi.org/10.1029/TR038i006p00913

[3] Martz, L. W., Garbrecht, J.: Numerical definition of drainage networks and subcatchment areas from digital elevation models, Computers and Geosciences 18, (1992) pp. 747-761. https://doi.org/10.1016/0098-3004(92)90007-E

[4] Ruszkiczay-Rüdiger, Zs., Fodor, L., Horváth, E., Telbisz, T.: Discrimination of fluvial, eolian and neotectonic features in a low hilly landscape: A DEM-based morphotectonic analysis in the Central Pannonian Basin, Hungary, Geomorphology 104 (3-4), (2009) pp. 203-217. https://doi.org/10.1016/j.geomorph.2008.08.014

[5] Jordán, Gy.: Terrain modelling with GIS for tectonic geomorphology. Numerical methods and applications. PhD Thesis, Acta Universitatis Upsaliensis, Uppsala, 2004., 42 p.

[6] Hegedűs, A.: Felszínalaktani vizsgálatok az Ózd-Pétervásárai dombságon, Doktori $(\mathrm{PhD})$ értkezés, Miskolci Egyetem, Miskolc, 2008., 109 p.

[7] Tribe, A.: Automated recognition of valley lines and drainage networks from grid digital elevation models: a review and a new method, Journal of Hydrology 139, (1992) pp. 263-293. https://doi.org/10.1016/0022-1694(92)90206-B

[8] Gallant, J. C., Dowling, T. I.: A multiresolution index of valley bottom flatness for mapping depositional areas, Water Resources Research, 39 (12), (2003) pp. 1347-1359. https://doi.org/10.1029/2002WR001426

[9] Jenness, J.: Topographic Position Index (tpi_jen.avx) extension for ArcView 3.x, v. 1.3a. http://www.jennessent.com/arcview/tpi.htm, 2006.

[10] Weiss, A.: Topographic Position and Landforms Analysis, Poster presentation, 2001 ESRI User Conference, San Diego, CA.

[11] Demeter G., Szabó Sz.: A völgyhálózat és törésirányok kapcsolatának vizsgálata különbözö geoinformatikai módszerekkel a Bükk északi elöterén, HunDEM 2009 és GeoInfo 2009 Konferencia, Miskolc, pp. 1-20.

[12] Vágó, J.: A közetminöség szerepe a Bükkalja völgy-és vizhálózatának kialakulásában, Doktori (PhD) értekezés, Miskolci Egyetem, Miskolc, 2012., 111 p.

[13] Balogh, K.: A Bükk hegység és környékének földtani térképe 1: 100 000, MÁFI, 1963.

[14] Less, Gy., Kovács S., Pelikán, P., Pentelényi, L., Sásdi, L.: A Bükk hegység földtana. Magyarázó a Bükk hegység földtani térképéhez (1:50 000), 2005., ISBN 9636712530

[15] Petrik, A.: A Bükk déli elöterének kainozoos szerkezetalakulása, Doktori (PhD) értekezés, ELTE-TTK, Budapest, 2016., 264 p.

[16] Pecsmány, P., Vágó, J.: A mélyszerkezet és a domborzat közötti kapcsolat a Bükkalja területén, Müszaki Földtudományi Közlemények 89, (2020) pp. 29-34. 